\title{
Chronic Granulomatous Disease with Associated IgG4-Related Disease: A Case Report and Review of the Literature
}

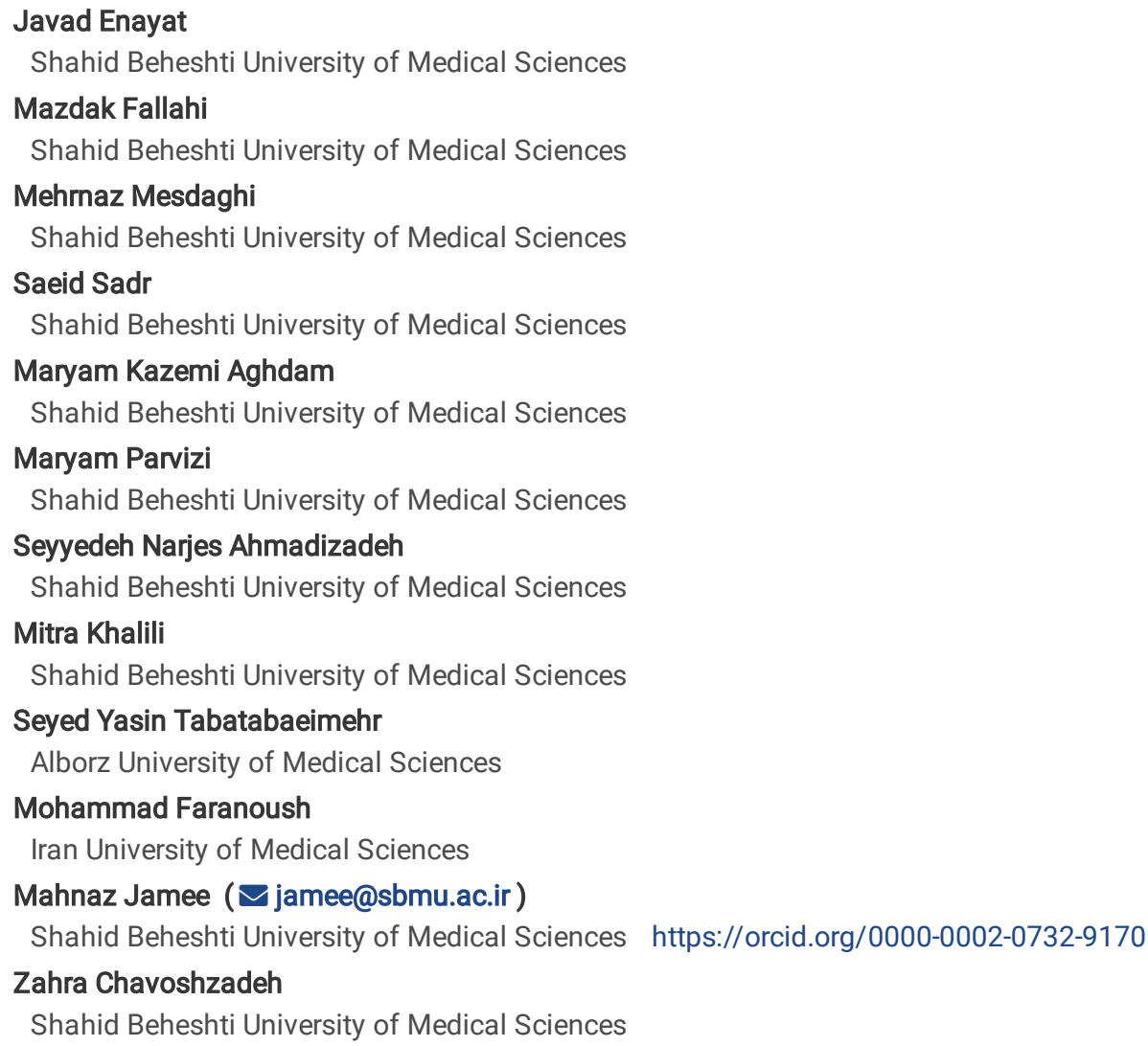

Shahid Beheshti University of Medical Sciences

Mazdak Fallahi

Shahid Beheshti University of Medical Sciences

Mehrnaz Mesdaghi

Shahid Beheshti University of Medical Sciences

Saeid Sadr

Shahid Beheshti University of Medical Sciences

Maryam Kazemi Aghdam

Shahid Beheshti University of Medical Sciences

Maryam Parvizi

Shahid Beheshti University of Medical Sciences

Seyyedeh Narjes Ahmadizadeh

Shahid Beheshti University of Medical Sciences

Mitra Khalili

Shahid Beheshti University of Medical Sciences

Seyed Yasin Tabatabaeimehr

Alborz University of Medical Sciences

Mohammad Faranoush

Iran University of Medical Sciences

Mahnaz Jamee ( $\sim$ jamee@sbmu.ac.ir)

Shahid Beheshti University of Medical Sciences https://orcid.org/0000-0002-0732-9170

Zahra Chavoshzadeh

Shahid Beheshti University of Medical Sciences

\section{Case report}

Keywords: IgG4-related disease, IgG4RD, chronic granulomatous disease, CGD, pulmonary, mass, inborn errors of immunity

Posted Date: July 8th, 2021

DOI: https://doi.org/10.21203/rs.3.rs-673553/v1

License: (c) (i) This work is licensed under a Creative Commons Attribution 4.0 International License. Read Full License 


\section{Abstract}

Background

IgG4-related disease (IgG4RD) may initially present with pulmonary pseudotumor, making the diagnosis challenging particularly in patients prone to granulomatous inflammation. Here, we describe the first case of chronic granulomatous disease (CGD) with associated IgG4RD.

Case presentation

An 8.5-year-old male was hospitalized two years ago with exertional dyspnea, mild cough, chest pain, and nocturnal sweating and was found to have a tumor-like mass in the right lung. The histopathologic findings were consistent with non-necrotizing granulomatous inflammation, central neutrophilic micro-abscess, and extensive peripheral fibrosis without any evidence for acid-fast bacilli or fungal elements. Treatment with prednisolone resulted in considerable symptom resolution. After 15 months, following the discontinuation of prednisolone by the patient, symptoms recurred, gradually exacerbated, and he developed anorexia and weight loss. The next chest spiral computed tomography (CT) scan showed a larger mass in the right lung, right lung collapse, and mediastinal metastasis. The abdominal ultrasound and CT scan were normal. In laboratory evaluation, low counts of B and T cells, normal natural killer (NK) cells, high levels of IgG4, and high inflammatory markers were detected. The nitro blue tetrazolium (NBT) test was zero in two consecutive evaluations. In virtue of high IgG4 level, the immunostaining of lung specimen was performed which was inconclusive for IgG4+cells, and staining for CD138 was not available. He was diagnosed with concurrent CGD and IgG4RD, but progressed to respiratory failure and died despite the reinstitution of steroid therapy.

\section{Conclusions}

The overlap between inborn errors of immunity (IEls) and IgG4RD is not common. Further studies to investigate IgG subsets among IEI patients can help elucidate clinicopathological correlations between these two immune-mediated disorders.

\section{Background}

Chronic granulomatous disease (CGD) is a group of inherited disorders of phagocytes, resulting from mutations in the components of the NADPH oxidase complex, reduced or absent oxygen radical synthesis, and impaired killing of intracellular bacteria and fungi (1). CGD patients typically present with recurrent life-threatening infections and granulomatous inflammatory responses in multiple organs, particularly the lungs (2). It is estimated that pneumonia and chronic pulmonary disorders complicate more than half of the CGD patients and are the major reasons for hospitalization $(3,4)$. The chronic inflammatory response may show up as granuloma formation and pulmonary fibrosis, particularly in long-term disease $(5,6)$. Lung granulomas, depending on their location, may manifest as obstructive airway disease and can mimic pulmonary tumor or fungal mass (7).

IgG4-related disease (IgG4RD) is a systemic inflammatory disorder, characterized by infiltration of IgG4 ${ }^{+}$plasma cells in different tissues, fibrotic change, and often elevated serum IgG4 (8). Pulmonary involvement of IgG4RD may be asymptomatic or mild at presentation and include hilar or mediastinal lymphadenopathies, nodules, bronchiectasis, pleural disorders, and neoplasia or interstitial lung disease mimicker lesions (9, 10). The latter is clinically important in the differential diagnosis of lung mass, particularly in patients with immunologic abnormalities.

There are few studies in the literature reporting patients with both IgG4-RD and inborn errors of immunity and the association between these two immune-mediated disorders is barely understood. Herein, we presented the first report of pediatric IgG4RD and chronic granulomatous disease (CGD).

\section{Case Presentation}

An 8.5-year-old male presented with complaints of dyspnea. He was the third child of non-consanguineous parents and the family history was unremarkable.

He was hospitalized two years ago with exertional dyspnea, mild cough, chest pain, and nocturnal sweating and was found to have a tumor-like mass in the right lung. In the chest MRI obtained at the last admission, the mass had a diameter of $52 * 15^{\star} 61$ millimeters with invasion to atria, completely obstructing the right upper lobe bronchus and both right pulmonary veins.

The histopathologic findings were consistent with non-necrotizing granulomatous inflammation, central neutrophilic micro-abscess, and extensive peripheral fibrosis without any evidence for acid-fast bacilli or fungal elements.

Treatment with prednisolone resulted in considerable symptom resolution. After 15 months, following the discontinuation of prednisolone by the patient, symptoms recurred, gradually exacerbated, and he developed anorexia and weight loss. 
On the physical examination, respiratory distress, absent sound on auscultation, and dullness on percussion of the right lung were detected. The chest spiral computed tomography (CT) scan showed a large mass in the right lung, right lung collapse, and mediastinal metastasis (Figure 1). The abdominal ultrasound and CT scan were normal.

In laboratory evaluation, the complete blood count, leukocyte differentiation, lactate dehydrogenase, and liver function tests were normal, however, inflammatory markers (erythrocyte sedimentation rate (ESR): 112, C-reactive protein (CRP):108) were high.

In immunologic workup, low T CD3 ${ }^{+}$, low T CD4 ${ }^{+}$, low T CD8 ${ }^{+}$, low B CD19 ${ }^{+}$, low T CD20 ${ }^{+}$, and normal NK cells were detected and serum immunoglobulin levels included IgG: 2530, IgM: 178, IgA: 151, IgG1: 1885, IgG2: 561, IgG3: 32, and IgG4: 311 (normal range: 2.3-189) (Table 1). The nitro blue tetrazolium (NBT) test was zero in two consecutive evaluations. In virtue of high lgG4 level, the immunostaining of lung specimen was performed which was inconclusive for $\operatorname{lgG} 4^{+}$cells, and staining for CD138 was not available.

He was eventually diagnosed with concurrent CGD and IgG4RD, but progressed to respiratory failure and died despite the reinstitution of steroid therapy.

\section{Discussion And Conclusions}

In this study, we presented the first report of pediatric IgG4RD and chronic granulomatous disease (CGD). The patient presented with dyspnea, mild cough, chest pain, and progressive dyspnea and had a tumor-like mass in the right lung, obstructing the airways. Following immunologic evaluation, he was diagnosed with CGD with high serum levels of IgG4. Although the histopathologic findings of lung mass were non-specific, we assume IgG4RD as the underlying etiology.

In recent years, some studies reported patients with both IgG4-RD and variable types of inborn errors of immunity (Table 2). In 2013, Langan reported a 65-year-old female who was previously diagnosed with the autoimmune lymphoproliferative syndrome (ALPS) with FAS mutation (c. 1074delT, p. L278fs*). She had diffused pancreatic lesion, salivary gland enlargement, and right eye proptosis due to the prominence of lacrimal glands. In the microscopic evaluation of lacrimal glands, dense lymphocytic infiltration and a high number of IgG4 positive plasma cells were observed. The pancreatic lesion was eventually diagnosed as autoimmune pancreatitis and improved by steroid therapy (11).

Another ALPS patient with associated IgG4RD was recently described by Van de ven et al (12). A 26-year-old male presented with lymphadenopathy, splenomegaly, and multiple renal masses. Renal biopsy exhibited monomorphic infiltration of T CD $3^{+}$lymphocytes and tubular damage. In immunologic evaluation, hypergammaglobulinemia, high serum cobalamin, interleukin (IL) -2 receptor, IL-10, and Fas ligand were identified and the genetic study confirmed the diagnosis of ALPS. He later developed acute pancreatitis and became resistant to rapamycin. The pancreatic biopsy showed lobular fibrosis and infiltrates containing eosinophils, T CD4 ${ }^{+}$lymphocytes, and plasma cells (mainly IgG4 positive) and the diagnosis of IgG4RD was established. To clarify the association between IgG4RD and ALPS, they also measured IgG4 in 18 ALPS-FAS patients and found elevated IgG4 in four patients, although at lower levels than the index patient.

The underlying immune dysregulation in ALPS, including reduced tumor necrosis factor alpha (TNF-a) expression and apoptosis of immune cells, and altered T helper 2 and T regulatory profile may explain the clinical association with IgG4RD (11). In addition, Fas mutation itself may contribute to the development of autoantibody-producing plasmablasts and a specific population of T cells (CD $4^{+}$granzyme $\mathrm{A}^{+}$), mediating fibrosis (12). Although most of the patients with ALPS represent high levels of IgG (78.5\%) (13), in those with organ lymphocytic infiltration and refractoriness to treatment, it would be reasonable to look for high levels of IgG4 and possibly IgG4RD.

In 2015, Rapisarda et al. reported a 43-year-old male initially presented with cholestatic jaundice, pancreatic mass, and hepatomegaly. Later, he developed atypical interstitial pneumonitis, pulmonary nodules, lymphadenopathy, and splenomegaly with associated severe lymphopenia (including reduced $\mathrm{CD} 4^{+} \mathrm{T}$ cell level), hypergammaglobulinemia, and increased inflammatory markers. The symptoms improved by the administration of glucocorticoids but recurred three years later. He also suffered from tubulointerstitial nephritis, decreased renal function, and hypocomplementemia. He was finally diagnosed with idiopathic CD4 lymphocytopenia and IgG4RD and treated with prednisolone.

The first report of IgG4RD in a pediatric patient with immunodeficiency was presented by Szczawinska-Poplonyk et al (14). The patient was a 7year-old male with a history of allergic rhinitis and bronchitis who presented with fever, respiratory distress, and lymphadenopathy. Pneumonia was suspected but did not improve with intravenous antibiotics. A consolidated mass was detected through the chest CT scan and surgically removed. The histopathology showed infiltration of lymphoplasmacytes, fibrosis, and vasculitis. Laboratory workup revealed increased CD ${ }^{+} \mathrm{T}$ cell, decreased $\mathrm{CD} 4^{+} \mathrm{T}$ cell, decreased memory B cells, EBV viremia, and no autoantibodies. He was diagnosed with IgG4RD and improved without complication.

Further studies on patients with inborn errors of immunity with clinical presentations of IgG4RD is required to elucidate possible common pathologic pathway between these two immune-mediated disorders. Along with searching for possible susceptibility variants that drive class switching to IgG4 and clonal expansion of $\mathrm{CD} 4^{+}$cytotoxic T cells (15), the role of epigenetic factors such as exposure to variable organisms in the 
context of immunodeficiency should not be neglected. As IgG4RD is recurrent in nature, after the diagnosis was established, close monitoring of patients would prevent irreversible organ damage.

\section{Abbreviations}

ALPS; autoimmune lymphoproliferative syndrome

CGD; chronic granulomatous disease

CRP; C-reactive protein

CT; computed tomography

ESR; erythrocyte sedimentation rate

IEls; inborn errors of immunity

IgG4RD; IgG4-related disease

IL; interleukin

NBT; nitro blue tetrazolium

NK; natural killer

TNF-a; tumor necrosis factor alpha

\section{Declarations}

Ethics approval and consent to participate: Informed consent was obtained from the patient and parents of the patient prior to being included in the study.

Consent for publication: Written consent for publication was taken from the patient and his parents.

Availability of data and materials: Not applicable.

Competing interests: The authors declare that they have no conflict of interest.

Funding: The authors received no specific funding for this research.

Authors' contributions: $\mathrm{ZCH}, \mathrm{JE}$, and MJ contributed to the conceptualization, data curation, supervision, and writing the original draft; ZCH, JE, MF, SS, SNA, and MF diagnosed and managed the patient when he was alive. MM determined the immunologic profile, MKA and MP read the pathology sections, and MKH performed the imagings. MF, MJ, and SYT gathered patient's data. All authors read and approved the final manuscript.

Acknowledgments: We thank the patient and his family for their contribution to this study.

\section{References}

1. Yu HH, Yang YH, Chiang BL. Chronic Granulomatous Disease: a Comprehensive Review. Clinical reviews in allergy \& immunology. 2020.

2. Kulkarni M, Desai M, Gupta M, Dalvi A, Taur P, Terrance A, et al. Clinical, immunological, and molecular findings of patients with p47 phox defect Chronic Granulomatous Disease (CGD) in Indian families. Journal of clinical immunology. 2016;36(8):774-84.

3. Henrickson SE, Jongco AM, Thomsen KF, Garabedian EK, Thomsen IP. Noninfectious manifestations and complications of chronic granulomatous disease. Journal of the Pediatric Infectious Diseases Society. 2018;7(suppl_1):S18-S24.

4. Campos LC, Di Colo G, Dattani V, Braggins H, Kumararatne D, Williams AP, et al. Long-term outcomes for adults with chronic granulomatous disease in the United Kingdom. The Journal of allergy and clinical immunology. 2021;147(3):1104-7.

5. Yao Q, Zhou QH, Shen QL, Qiao ZW, Wang XC, Hu XH. Imaging findings of pulmonary manifestations of chronic granulomatous disease in a large single center from Shanghai, China (1999-2018). Scientific reports. 2020;10(1):19349.

6. Martire B, Rondelli R, Soresina A, Pignata C, Broccoletti T, Finocchi A, et al. Clinical features, long-term follow-up and outcome of a large cohort of patients with chronic granulomatous disease: an Italian multicenter study. Clinical immunology. 2008;126(2):155-64. 
7. Mahdaviani SA, Mohajerani SA, Rezaei N, Casanova J-L, Mansouri SD, Velayati AA. Pulmonary manifestations of chronic granulomatous disease. Expert review of clinical immunology. 2013;9(2):153-60.

8. Karim F, Loeffen J, Bramer W, Westenberg L, Verdijk R, van Hagen M, et al. IgG4-related disease: a systematic review of this unrecognized disease in pediatrics. Pediatric rheumatology online journal. 2016;14(1):18.

9. Grewal K, Cohen P, Kwon JS, Kaufman DA. IgG4-related disease presenting as a lung mass and weight loss: Case report and review of the literature. Respir Med Case Rep. 2016;17:27-9.

10. Pandita A, Wong J. IgG4-related disease in lung: a diagnostic challenge. Pathology. 2020;52(3):390-2.

11. Langan RC, Gill F, Raiji MT, Mullinax JE, Pittaluga S, Pandalai P, et al. Autoimmune pancreatitis in the autoimmune lymphoproliferative syndrome (ALPS): a sheep in wolves' clothing? Pancreas. 2013;42(2):363-6.

12. van de Ven A, Seidl M, Drendel V, Schmitt-Graeff A, Voll RE, Rensing-Ehl A, et al. IgG4-related disease in autoimmune lymphoproliferative syndrome. Clinical immunology (Orlando, Fla). 2017;180:97-9.

13. Hafezi N, Zaki-Dizaji M, Nirouei M, Asadi G, Sharifinejad N, Jamee M, et al. Clinical, immunological, and genetic features in 780 patients with autoimmune lymphoproliferative syndrome (ALPS) and ALPS-like diseases: A systematic review. Pediatric allergy and immunology : official publication of the European Society of Pediatric Allergy and Immunology. 2021.

14. Szczawinska-Poplonyk A, Wojsyk-Banaszak I, Jonczyk-Potoczna K, Breborowicz A. Pulmonary manifestation of immunoglobulin G4-related disease in a 7-year-old immunodeficient boy with Epstein-Barr virus infection: a case report. Italian journal of pediatrics. 2016;42(1):58.

15. Mattoo H, Stone JH, Pillai S. Clonally expanded cytotoxic CD4(+) T cells and the pathogenesis of IgG4-related disease. Autoimmunity. 2017;50(1):19-24.

\section{Tables}




\begin{tabular}{|c|c|c|}
\hline Parameters (unit) & Results & Normal ranges \\
\hline WBC $\times 10^{3}($ cell/uL $)$ & 15.2 & $6000-17000$ \\
\hline Absolute lymphocytes count, cells $/ \mu \mathrm{L}$ & 608 & $3000-9500$ \\
\hline Absolute neutrophils count, cells $/ \mu \mathrm{L}$ & 13680 & $1500-8500$ \\
\hline $\operatorname{RBC}\left(\times 10^{6} / \mathrm{ul}\right)$ & 3.85 & $4.0-5.2$ \\
\hline $\mathrm{Hb}(\mathrm{gr} / \mathrm{dL})$ & 10.4 & $11.5-15.5$ \\
\hline Platelet $\left(\times 10^{3} / \mathrm{ul}\right)$ & 249 & $150-450$ \\
\hline CD3+ T cells, \%, cell/ $\mu \mathrm{L}$ & $77.4 \%, 527$ & $1200-2600$ \\
\hline CD4+ T cells, \%, cell/ $\mu \mathrm{L}$ & $38.6 \%, 263$ & $650-1500$ \\
\hline CD8+ T cells, \%, cell/ $\mu \mathrm{L}$ & $34.0 \%, 232$ & $370-1100$ \\
\hline $\mathrm{CD}_{19}{ }^{+} \mathrm{B}$ cells, \%, cell/ $\mu \mathrm{L}$ & $2.0 \%, 14$ & $270-860$ \\
\hline $\mathrm{CD}_{20}{ }^{+} \mathrm{B}$ cells, $\%$, cell $/ \mu \mathrm{L}$ & $1.0 \%, 7$ & $270-860$ \\
\hline CD16 ${ }^{+}$NK cells, $\%$ & $11.6 \%$ & $5-19$ \\
\hline CD56 ${ }^{+}$NK cells, $\%$ & $14.3 \%$ & $3-15$ \\
\hline CD16 $56^{+} \mathrm{NK}$ cells, $\%$ & $8.9 \%$ & 4-17 \\
\hline $\operatorname{lgG}(\mathrm{mg} / \mathrm{dL})$ & 2530 & $>700$ \\
\hline $\operatorname{lgM}(\mathrm{mg} / \mathrm{dL})$ & 178 & $>80$ \\
\hline $\operatorname{lgA}(\mathrm{mg} / \mathrm{dL})$ & 151 & $>100$ \\
\hline $\lg E(\mathrm{mg} / \mathrm{dL})$ & $>400$ & Up to 68 \\
\hline NBT & 0 & $>90$ \\
\hline Diphtheria Ab (IU/mL) & 0.2 & $>0.01$ \\
\hline Anti-Tetanus Ab (IU/mL) & 0.14 & $>0.1$ \\
\hline PT (sec) & 14 & $9.6-12.2$ \\
\hline INR & 1.3 & $0.8-1.15$ \\
\hline PTT (sec) & 30 & Up to 48 \\
\hline BUN (mg/dL) & 6.8 & $7-17$ \\
\hline Creatinine (mg/dL) & 0.53 & $0.4-1$ \\
\hline $\mathrm{Na}(\mathrm{meq} / \mathrm{L})$ & 133 & $135-148$ \\
\hline $\mathrm{K}(\mathrm{meq} / \mathrm{L})$ & 4.4 & $5.3-4.1$ \\
\hline$P(\mathrm{mg} / \mathrm{dL})$ & 3.3 & $3-7$ \\
\hline $\mathrm{Ca}(\mathrm{mg} / \mathrm{dL})$ & 8.1 & $8.6-10.3$ \\
\hline ALK P (U/L) & 305 & $180-1200$ \\
\hline AST (U/L) & 40 & $<37$ \\
\hline ALT (U/L) & 38 & Up to 41 \\
\hline Uric acid (mg/dL) & 2.5 & $3-6.4$ \\
\hline $\mathrm{Mg}(\mathrm{mg} / \mathrm{dL})$ & 2.2 & $1.5-2.3$ \\
\hline LDH Serum (U/L) & 445 & $290-140$ \\
\hline Bilirubin $\mathrm{T}(\mathrm{mg} / \mathrm{dL})$ & 1.5 & $0.1-1.2$ \\
\hline
\end{tabular}




\begin{tabular}{|lll|}
\hline \multicolumn{3}{|l|}{ Table 1 - Summary of laboratory findings at the last admission } \\
\hline Parameters (unit) & Results & Normal ranges \\
\hline Bilirubin D (mg/dL) & 0.5 & $<0.3$ \\
\hline CRP $(\mathrm{mg} / \mathrm{dL})$ & 108 & Up to 6 \\
\hline ESR $(\mathrm{mg} / \mathrm{dL})$ & 112 & $0-10$ \\
\hline
\end{tabular}

Table 2 - The overlap between IEls and IgG4RD

\begin{tabular}{|c|c|c|c|c|c|c|c|c|}
\hline $\begin{array}{l}P t \\
I D\end{array}$ & $\begin{array}{l}\text { Age, } \\
\text { Sex }\end{array}$ & IEI Type & IgG4RD Evidence & $\begin{array}{l}\text { Clinical } \\
\text { Manifestations }\end{array}$ & $\begin{array}{l}\text { Organ of } \\
\text { lgG4+ cell } \\
\text { infiltration }\end{array}$ & Treatment & Outcome & $\begin{array}{l}\text { Reference, } \\
\text { Country }\end{array}$ \\
\hline P1 & $\begin{array}{l}26 \\
\text { Male }\end{array}$ & $\begin{array}{l}\text { Autoimmune } \\
\text { lymphoproliferative } \\
\text { syndrome }\end{array}$ & $\begin{array}{l}\text { IgG4: } 6500 \text {, } \\
\text { IgG4+ plasma cell } \\
\text { infiltration, High } \\
\text { CD20-CD38++CD27+ } \\
\text { plasmablasts }\end{array}$ & $\begin{array}{l}\text { Organomegaly, } \\
\text { Multiple masses in } \\
\text { the renal cortex, } \\
\text { Acute pancreatitis }\end{array}$ & $\begin{array}{l}\text { Pancreas, } \\
\text { Lymph } \\
\text { node }\end{array}$ & $\begin{array}{l}\text { Rapamycin, } \\
\text { Steroids }\end{array}$ & Alive & $\begin{array}{l}\text { Van de ven et } \\
\text { al, 2017, } \\
\text { Germany }\end{array}$ \\
\hline P2 & 7, Male & $\begin{array}{l}\text { Adaptive immune } \\
\text { abnomality and } \\
\text { EBV infection }\end{array}$ & $\begin{array}{l}\text { High CD138+ plasma } \\
\text { cells, IgG4+ plasma } \\
\text { cell infiltration, } \\
\text { Storiform fibrosis, } \\
\text { Obliterative vascular } \\
\text { lesions }\end{array}$ & $\begin{array}{l}\text { Chest pain, Fever, } \\
\text { Lymphadenopathy, } \\
\text { Lung mass }\end{array}$ & Lung & $\begin{array}{l}\text { Antibiotics, } \\
\text { Surgical } \\
\text { removal of } \\
\text { mass }\end{array}$ & Alive & $\begin{array}{l}\text { Szczawinska- } \\
\text { Poplonyk et } \\
\text { al, 2016, } \\
\text { Poland }\end{array}$ \\
\hline P3 & $\begin{array}{l}43 \\
\text { Male }\end{array}$ & $\begin{array}{l}\text { Idiopathic CD4 } \\
\text { Lymphocytopenia }\end{array}$ & $\begin{array}{l}\text { Hypocomplementemia, } \\
\text { Increased } \\
\text { polyclonal lgG and } \\
\text { lgG4 subclass, } \\
\text { increased kidney } \\
\text { volume }\end{array}$ & $\begin{array}{l}\text { Organomegaly, } \\
\text { Pancreatic mass, } \\
\text { Jaundice, Enlarged } \\
\text { salivary gland, } \\
\text { Interstitial } \\
\text { nephritis, EBV and } \\
\text { CMV infection, } \\
\text { Interstitial } \\
\text { pneumonia, Lung } \\
\text { nodules }\end{array}$ & Kidney & Steroids & Alive & $\begin{array}{l}\text { Rapisarda et } \\
\text { al, 2015, Italy }\end{array}$ \\
\hline P4 & $\begin{array}{l}\text { 65, } \\
\text { Female }\end{array}$ & $\begin{array}{l}\text { Autoimmune } \\
\text { lymphoproliferative } \\
\text { syndrome }\end{array}$ & $\begin{array}{l}\text { Dense } \\
\text { lymphocytic infiltrate, } \\
\text { lgG4+ plasma cell } \\
\text { infiltration }\end{array}$ & $\begin{array}{l}\text { Enlarged salivary } \\
\text { gland, Proptosis, } \\
\text { Pancreatic lesions }\end{array}$ & $\begin{array}{l}\text { Lacrimal } \\
\text { gland, } \\
\text { Pancreas }\end{array}$ & Steroids & Alive & $\begin{array}{l}\text { Langan et al, } \\
2013 \text {, USA }\end{array}$ \\
\hline
\end{tabular}

\section{Figures}
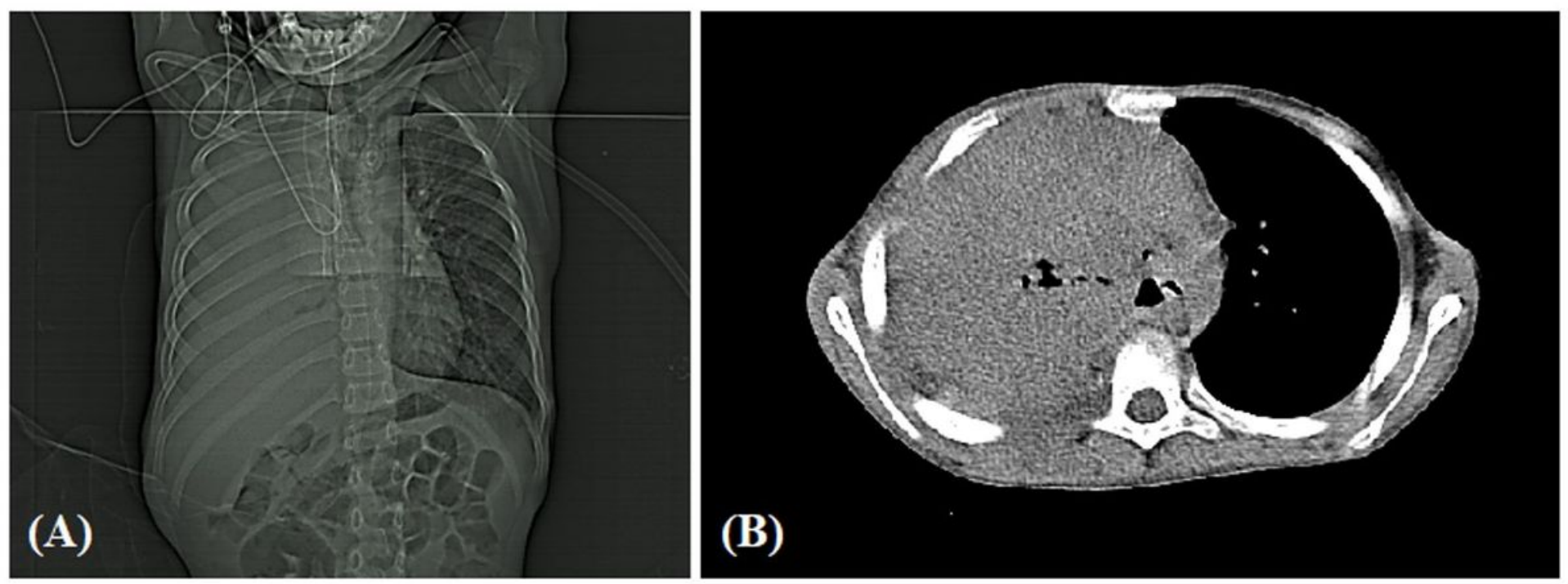

Figure 1

A. Complete opacity in the right lung was detected in chest X-ray. B. The chest spiral CT scan showed a large mass in the right lung, right lung collapse, and mediastinal metastasis. 